\title{
Analysis of the level of disclosure of the mission statements of large Brazilian companies ${ }^{\star * *}$
}

\author{
Emanuel Junqueira ${ }^{1}$ \\ (D) https://orcid.org/0000-0002-0822-3570 \\ Email: emanuel.matos@ufes.br \\ Reinaldo Camacho ${ }^{2}$ \\ (D) https://orcid.org/0000-0003-2771-9376 \\ Email: rrcamacho@uem.br \\ Eric Ferreira dos Santos ${ }^{3}$ \\ (D) https://orcid.org/0000-0002-4602-7263 \\ Email: eric.santos@kroton.com.br
}

\begin{abstract}
${ }^{1}$ Universidade Federal do Espirito Santo, Departamento de Ciências Contábeis, Vitória, ES, Brazil
${ }^{2}$ Universidade Estadual do Maringá, Departamento de Ciências Contábeis, Maringá, PR, Brazil

${ }^{3}$ Universidade Estadual de Londrina, Departamento de Ciências Contábeis, Londrina, PR, Brazil
\end{abstract}

Received on 05.09.2019 - Desk acceptance on 05.21.2019 - $4^{\text {th }}$ version approved on 04.23.2020

Editor-in-Chief: Fábio Frezatti

Associate Editor: Cláudio de Araújo Wanderley

\begin{abstract}
The aim of this study was to verify the level of disclosure of the survival, growth, and profitability (SGP) construct in the mission statements of Brazilian companies and in the collective discourse of different economic sectors, classified according to the "Biggest \& Best" Annual published by Exame Magazine. The research seeks to fill the gap in the field by studying the disclosure of the SGP construct in the mission statements of large Brazilian companies. Considering the mission statement as the genesis of strategic planning, an analysis of the disclosure of the SGP construct allows for a discussion of the relevance of the contribution of the mission statement to the elaboration, implementation, and monitoring of that planning. The benefit of a mission statement aligned with the strategic planning lies in adequate communication to the stakeholders regarding the long-term SGP goals, based on the assumption that comprehensive and objective communication minimizes the risks of failures during the management process. Collective subject discourse (CSD) was used to develop a qualification metric of the constitutive elements of the organizational mission statements, enabling it to be identified whether the Brazilian companies, grouped into different economic sectors, are smoothing, concealing, or omitting the construct formed by the SGP components in their mission statements. This study investigates the presence or not of the SGP components in the collective discourse of mission statements of 220 large Brazilian companies. Most of the companies analyzed in the sample do not include SGP in their mission statements and those that do discuss it with discursive vagueness, lacking clarity in their disclosure of the components. For the academia, this finding contributes to understanding the constituent components of the mission statements of large Brazilian companies. For organizations, the findings indicate the need to reflect on the content to be used in the formulation of their mission statements.
\end{abstract}

Keywords: mission statement, profitability, concealment, collective subject discourse.

Correspondence address

Emanuel Junqueira

Universidade Federal do Espirito Santo, Departamento de Ciências Contábeis

Avenida Fernando Ferrari, 514 - CEP 29075960

Goiabeiras - Vitória - ES - Brazil

* Article presented at the XIII ANPCONT Congress, São Paulo, SP, Brazil, June of 2019.

** The authors are grateful to the Espírito Santo Research and Innovation Support Foundation (FAPES) for its financial support to carry out this research. 


\section{INTRODUCTION}

An organization's mission statement is an expression of the company's reason for existing and should be aligned with the main stakeholders' values and expectations and reveal the scope, business direction, and boundaries of the organization (Graham \& Havlick, 1994; Johnson et al., 2009). It can be considered the first step of the strategic planning process (Pearce \& David, 1987), playing a relevant role in the formulation of the organizational strategies (O'Gorman \& Doran, 1999). It is a critical step in the strategic management process (Certo \& Certo, 2012), as it should provide a direction for the managers (King \& Case, 2013), helping them in their decision making and reducing the risk of losing focus (McKee et al., 2012) by highlighting what the organization wants to be and who it wishes to serve (Berbegal-Mirabent et al., 2019).

The research conducted by Berbegal-Mirabent et al. (2019), Mussoi et al. (2011), Pearce (1982), Pearce and David (1987), and Souza et al. (2014) sought to identify the necessary components of a mission statement based on analyzing the mission statements of different groups of companies. Standing out among the information identified is that which portrays the concern with survival, growth, and profitability (O'Gorman \& Doran, 1999). This information is central to organizations (Graham \& Havlick, 1994) and is normally the most used in mission statements (O'Gorman \& Doran, 1999).

Despite the need to guide the strategic direction of the business, reflecting the company's intention to guarantee its survival through sustained growth and profitability (Pearce \& David, 1987), the information about the survival, growth, and profitability (SGP) construct is not always explicit and clear (Graham \& Havlick, 1994). This may hinder the implementation of the mission due to problems in communicating the long-term objectives to the various organizational players (Tonge et al., 2003).

The Theory of Rational Action (TRA) assumes that people use the available information to decide on their attitude (Fishbein, 1967; Fishbein \& Ajzen, 2015) and has as its main objectives (i) to predict and understand the individual's behavior and (ii) to stipulate the intention to carry out that behavior (Fishbein \& Ajzen, 1974). For this, Verma (2009) proposes applying rational thinking in the process of writing a mission statement, while Collis and Rukstad (2008) indicate that this should express the motivation to contribute to society based on what the company aspires to achieve (Collis \& Rukstad, 2008).

In this study, through collective subject discourse (CSD), the companies' mission statements are analyzed at a collective level, as if the economic sectors were self- expressing, enabling them to be understood concerning the communication related to SGP.

CSD is a methodology that retrieves the individual expressions of a same content that present similar meanings to group them into a collective discourse synthesis, as if it were a collective speaking as one individual (Lefevre \& Lefevre, 2014). CSD enables analyses of groups of companies, observing the discourse of the collective, while simultaneously preserving the primary meaning of the discourse of each company. Thus, it seeks to retrieve the collective thinking of the statements through the set of knowledge, beliefs, and ideas as an empirical reality that is self-expressed (Lefevre \& Lefevre, 2005).

Thus, this research aims to verify the level of disclosure of the SGP construct in the mission statements of Brazilian companies and in the collective discourse of different economic sectors, classified according to the Biggest \& Best Annual published by Exame Magazine.

The concern with the level of disclosure of the SGP construct derives from the need to adequately communicate the organization's long-term objectives, given that the inadequate establishment of a mission can create distrust among the stakeholders regarding what is stated and what is practiced. A discourse that differs from the actions can affect the organization's credibility, with effects on its profitability and, consequently, on the actions that seek survival, growth, and profitability (Demsetz, 1997).

The need to rationalize intentions advocated by the TRA suggests that the mission should be consciously and rationally stated by those responsible for its elaboration, avoiding concealment, which in this study corresponds to the absence of at least one of the components that form the SGP construct, making it imperceptible to the information user.

A clear, objective mission with no concealments can stimulate shareholder confidence that the management process will be developed with a greater likelihood of achieving the long-term organizational goals. In other words, the TRA argues that the inclusion or not of the SGP construct is intentional and its adequate disclosure expresses the valuation of the stakeholders. For example, a company may state its desire to obtain success in the activities it carries out, remunerating the capital invested by the shareholders and specifying that this remuneration should be above the average of the industry in which it operates. Conversely, when the SGP construct is not highlighted, the managers are thought to be concealing its disclosure, omitting the real aim of the organization. 
The typology of Pearce (1982) and Pearce and David (1987), on which this research is based, is observed in mission statements with a certain degree of regularity and consistency, demonstrating that companies understand the types of information they judge relevant to communicate to stakeholders. In this sense, it is expected that clearly and communicatively disclosed mission statements can have an impact on stakeholder behavior, on strategic planning, and, consequently, on the management process, with positive effects on organizational performance (Souza et al., 2014; Williams, 2008).

Considering the mission statement as the genesis of the management process, the presence of the SGP components in an organization's mission would enable its elaboration and implementation in a more communicative and efficient way for the shareholders and other stakeholders. Moreover, discursive analyses of the communication of missions contribute to academic discussions, as they provide valuable information about organizations' longterm strategic objectives.

Therefore, this study is warranted by the need to evaluate the level of disclosure of the SGP construct, identifying possible concealments and revealing the need for adjustments in companies' mission statements, with the aim of contributing to the strategic planning process and to the disclosure of the organizational objectives to the various stakeholders. In addition, the study may contribute to the researchers in the field better understanding the constituent components of the mission statements of large Brazilian companies, as well as whether the latter are concealing when disclosing SGP.

\section{THEORETICAL FRAMEWORK}

\subsection{TRA in the Context of Mission Statements}

As previously mentioned, the TRA argues that the writing of an organization's mission statement should be rationalized or deliberate before being executed by the managers and disclosed to the different stakeholders. Thus, there is the understanding that the intention to carry out a particular action precedes it actually being carried out. This is called behavioral intention. The TRA sustains the idea that intention results from a belief that the future execution of a behavior will cause a specific result (Fishbein, 1967; Fishbein \& Ajzen, 2015), and one of its main objectives is to specify the intention to carry out a particular behavior, this being the fruit of conscious choices (Fishbein \& Ajzen, 1975). Thus, a mission that adequately highlights the SGP construct would denote the organization's intention to achieve it, favoring communication with the stakeholders.

From the perspective of the TRA, Verma (2009) analyzed the requirements for the company mission, proposing that rational thinking should be contained in the process of writing a mission statement due to the fact that its content should be formed of fundamental elements that can influence the behavior of the people in the organization. That is, the assumption underlying the analysis of the company mission statement is that all the most important beliefs and referent modals will be included in it, though it is recognized that the rational elaboration of a mission statement may be difficult and unviable if the company's management is unwilling to indicate and acknowledge the real organizational objective (Bart, 1997).
The TRA suggests that when the intentions are communicated clearly and objectively they lead to a greater effort from people to achieve them, increasing the probability of success (Fishbein \& Ajzen, 2015). When that occurs, it is possible to identify the existence of an effort to execute the strategy and, in that process, it is possible to externalize what should be preserved, aspects that determine the organizational identity, and what may be altered (Moss et al., 2011; Verma, 2009). Thus, to help in the strategic planning process, the mission should be long-lasting, while strategies derived from it can vary according to the level of competition in the environment, for example, or other internal or external factors.

\subsection{Perspectives and Sense of Direction of Mission Statements}

Among the perspectives from which the literature on mission statements was developed from the 1980s onward, there is the perspective related to the identification and analysis of components based on typologies (Alegre et al., 2018; Pearce, 1982). From this perspective, the existence of rational writing is accepted, given that the mission statement is elaborated through the inclusion or not of predefined components (Pearce \& David, 1987). Mission statements conceive the corporate goal, understood as a company's "raison dêtre" (David, 1989; Ireland \& Hitt, 1992), and the scope of the distinction between one company and another (Bakoğlu \& Aşkun, 2007; David \& David, 2003)

As a critical element of the strategy, the mission must be expressed clearly and realistically (Campbell \& Yeung, 
1991a, 1991b) and derive from the definition of objectives, beliefs, and principles related to the strategic position, which are essential for strategic management and useful for control (David, 1989; Pearce, 1982).

Companies' mission statements in relation to society serve to: define the responsibilities of the business (Drucker, 1994); communicate the sense of direction and corporate goal, guiding the actions (Bartkus et al., 2000; Ireland \& Hitt, 1992); center the attention and resources on the important elements for the organization (Bart, 1997; Ireland \& Hitt, 1992); satisfy the employees' needs through the goal, motivating and inspiring them (Bartkus et al., 2000; Campbell, 1991); guide behaviors (Campbell, 1997); serve as a marketing item (Davies \& Glaister, 1997; Mussoi et al. 2011); guide the elaboration of objectives and strategies (Lipton, 1996); and help in decision making, serving as control mechanisms (Bartkus et al., 2000). On the other hand, there is evidence of mission statements being used for decorative purposes, without any practical goal (Verma, 2009).

Campbell and Yeung (1991a, p. 145) raise two selfreflexive questions for companies: "what is our business and what should it be?" According to the Theory of Organizational Identity (Albert \& Whetten, 1985), these questions can be reworded in the following way: "who are we as an organization?" The answers lie in the strategy, in its relationships with the stakeholders, and in the understanding of the missions, as a clear statement, as these favor rationality of actions, immanent to the culture and to the strategy (Campbell \& Yeung, 1991a).

\subsection{Components of the Mission Statement}

Organizational mission statements consist of sets of components (Pearce, 1982), the choice of which depends on the characteristics of the organization (Alegre et al., 2018) and its managers. When there is no rationality in their creation, they end up being created by companies without using any prescribed method for building them, which causes the variation in the number of components between mission statements (Campbell, 2001). Pearce (1982) and Pearce and David (1987) proposed the first typology with eight key components, including the survival, growth, and profitability components that form the SGP construct, the focus of this study.

Subsequently, the studies in the field have sought to operationalize the measurement of the components in different ways. Bart (1997), David and David (2003), and Sufi and Lyons (2003) analyzed the components by the frequency of their occurrence or mean inclusion, examining each mission record and attributing scores indicating the absence or presence of the components.
Mussoi et al. (2011) carried out a reading of phrases to identify the frequency of components based on the typologies using a checklist. Cady et al. (2011) ran a content analysis in 300 American mission statements, using a complex textual analysis methodology to analyze the occurrence of terms and concepts. In turn, Cochran et al. (2008) and Rajasekar (2013) analyzed the clarity, scope, and consistency of mission statements using legibility indicators. Regarding the scope of a mission statement, Bart (2006) suggests that a statement between 60 and 80 words has a reasonable size to be effective.

In general, the literature has described the components through an analysis of frequencies, means of inclusions, indicators, and textual analyses. Moreover, various economic sectors have been considered. Rajasekar (2013), for example, compared financial service, food, mining, gas, petroleum, energy, infrastructure, transport, and health companies, among others. The research of David and David (2003) focused on computing, food, and banking industries, while Sufi and Lyons (2003) investigated hospitality companies (restaurants and hotels). All the studies investigated the typology as a whole and did not analyze any specific component in depth.

\subsection{The SGP Construct}

The SGP construct evokes the question "what will the company's actions be in relation to the economic objectives?" (Pearce, 1982). The components that form the SGP construct represent the elements of the organizational goals and are the three keys for the strategic direction (Graham \& Havlick, 1994). When disclosing the SGP construct, the mission statement expresses the organization's intention to guarantee its survival through the growth or maintenance of its position in the market and its financial-economic viability (Graham \& Havlick, 1994).

The absence of the SGP construct in a mission statement indicates little strategic concern about the company's continuity, future, and growth (Najimudinova, 2018). Moreover, the lack of will to maximize profit and/ or minimize possible losses (Demsetz, 1997) may be sufficient reason for not mentioning the construct.

On the other hand, when the SGP construct does not present all the survival, growth, and profitability components, it may be seen as concealed. Concealment corresponds to omitting what is real and is observed when one or more components that compose the distinctive pattern of something real are hidden or suppressed (Gooch \& Perlmutter, 1982). Thus, in the context of organizational mission statements, concealment is understood as the absence of mentioning at least one of the three core components of the SGP construct. 
As previously highlighted, survival is a component of SGP and represents the company's capacity to maintain itself in the market (Phillips \& Kirchhoff, 1989), signaling its competitive position (Delmar et al., 2013). The growth component, in turn, can be understood as the expectation of sales growth, that is, of the share in the market in which it operates (Delmar et al., 2013; Graham \& Havlick, 1994). Although growth in market share is strongly correlated with company profitability, there are other important ways of measuring growth, such as (i) the number of markets served; (ii) the variety of products offered; and (iii) the variety of technologies used, among others. According to Pearce and David (1987), the management of these growth indicators also enables an improvement in the company's competitive capacity.

The profitability among the SGP components represents a company's main goal, as mentioning long-term profit is the sign of a clearer discourse on the organization's capacity to satisfy the stakeholders' demands (Graham \& Havlick, 1994). For some stakeholder groups, the mission represents the maximization of profit or investor return (Lipton, 1996). When there is no mention of this component, profit maximization ceases to be a variable that motivates people and no distinction is created between companies (Lipton, 1996).

When defending the alignment between the motivations of managers and collaborators to adjust their behaviors, Liang (2014) presents a maximization model that recognizes the three concepts, but in another way: a) maximization of return on sales (survival); b) maximization of growth in the value of capital in the long run; and c) maximization of profit in the long run.

Demsetz (1997) is skeptical and questions the real desire to maximize profits, arguing that the behavior of greedy companies is dubious as they do not react in the same way as those that see profit as a healthy incentive for growth. Schaffer (1989) clarifies that companies with market power are not necessarily the best survivors. That does not inhibit them from demonstrating their intentions to maximize profit, because the management and different policies enable them to do so (Demsetz, 1997).

Assuming that every company intends to maximize profits, according to Bakoğlu and Aşkun (2007), there is little mention of the profitability component in mission statements, because the collaborators are the most relevant internal stakeholders; for that reason, companies do not speak about profit to the external stakeholders as they understand that mentioning its maximization would not be enough to distinguish one organization from another. This appears to be valid for companies governed by economic rationality and by revenue and profit maximization (Moss et al., 2011).

Consequently, financial return, previously indicated by growth, is essential for a company's survival. For this reason, Delmar et al. (2013) understand that profitability leads to survival and growth to profitability, providing it is subject to survival. The three core concepts of the construct are inseperable, involving a kind of balance and influencing the theories of growth within the dynamics of the industry (Delmar et al., 2013).

\section{METHODOLOGY}

This study is characterized as exploratory because it specifically examines the SGP construct of organizational mission statements, more thoroughly and in-depth in relation to the previous studies that have looked at the variables proposed by Pearce (1982) and Pearce and David (1987) in a more generalist way. The research is also descriptive as it details and analyzes the components that form the SGP construct. For the qualitative analysis of the data, CSD was employed, which is a methodology that retrieves the individual expressions of a same content that present similar meanings to group them in a collective discourse synthesis, as if it were a collective speaking as one individual (Lefevre \& Lefevre, 2005, 2014).

The information about the companies' mission statements was obtained in May of 2018, using the stratified random sampling technique to preserve the representativeness of the discourses. The mission statements of 220 (44\%) companies from the 500 biggest firms listed in the Biggest and Best Companies in Brazil in 2017 ranking published by Exame Magazine were collected and analyzed. Following the classification proposed by the magazine, the companies were distributed into 23 sectors of the economy. Information was obtained regarding: i) sector, ii) type of control; iii) turnover; iv) growth percentage; v) profit margin; vi) return percentage; and vii) sales margin.

Among the 220 companies analyzed, 132 are under Brazilian control (605), 21 are state controlled (9.5\%), and 12 are under American control (5.5\%). These three types of control represent $75 \%$ of the sample. Other companies are under German (3.6\%) and French (2.7\%) control. The rest of the companies, totaling 42 (19.1\%), have their capital fragmented among other nationalities.

The strata were formed according to the classification by economic sector proposed by the magazine and composed as follows: Wholesale (21), Automotive Industry (11), Capital Goods (3), Consumer Goods (18), 
Communications (2), Various (2), Electronics (4), Energy (35), Pharmaceuticals (4), Construction Industry (7), Digital Industry (7), Infrastructure (7), Mining (3), Pulp and Paper (3), Agricultural Production (13), Chemicals and Petrochemicals (15), Health Services (11), Services (7), Steelmaking and Metallurgy (10), Telecommunications (4), Textiles (2), Transport (9), and Retail (22).

The mission statements of the companies analyzed were obtained from the institutional websites. Subsequently, the companies' mission statements underwent an organization and classification process, using the original typology of Pearce (1982) and Pearce and David (1987), with the aim of enabling greater comparability. Next, an analysis was carried out with the aim of identifying the presence of terms related with the SGP construct such as, for example, "shareholders," "return," "growth," and "profitability." This stage enabled the identification of the companies that would be considered in the analysis of the level of disclosure of the sectors studied.
Similarly to what is seen by David and David (2003), the following measure was employed to categorize the presence or absence of the SGP construct: 1 for the presence and 0 for the absence of the component. The same procedure was adopted for each component of the SGP construct.

After identifying the presence of the SGP construct and which constructs were highlighted in the mission statement, the terms, words, and characters of the construct and of the components present were counted. After this stage, it was possible to build the CSD of the sectors studied.

To operationalize the stages described, a discourse qualification and evaluation methodology was created (Table 1), inspired by Cochran et al. (2008) and Gunning and Kallan (1994), which enabled the disclosure evaluation and characterization in terms of silence, concealment, balance, and expressivity to assess the content of the mission statements with regards to the SGP construct.

\section{Table 1}

Operational definition of the discourse qualification indicators

\begin{tabular}{|c|c|c|}
\hline Qualifier & Formula & Operational definition \\
\hline Type 1 omission & $1-\frac{A C x}{C S x}$ & $\begin{array}{l}\text { Proportion of non-inclusion of the SGP construct, considering the sampling } \\
\text { volume of companies of the sector. }\end{array}$ \\
\hline Type 2 omission & $\frac{\left(\frac{C x}{P}\right)}{C S x}$ & $\begin{array}{l}\text { Ratio of characters per word of the SGP construct over the sampling volume of } \\
\text { companies of the sector. Shows the level of detail or simplification (omission) of } \\
\text { the discourse. }\end{array}$ \\
\hline $\begin{array}{l}\text { Global relative } \\
\text { disclosure }\end{array}$ & $\left(\frac{C 1}{C S 1}+\ldots+\frac{C 8}{C S 8}\right)$ & $\begin{array}{l}\text { Sum of the volume of characters of each SGP construct over the sampling volume. } \\
\text { Identifies the level of expressivity of a mission as a whole. An average score of } \\
\qquad 12.5 \% \text { ( } 1 / 8 \text { constructs) is expected for each construct. }\end{array}$ \\
\hline Relative disclosure & $\frac{C 5}{C S 5} /\left(\frac{C x}{C S 1}+\ldots+\frac{C 8}{C S 8}\right)$ & $\begin{array}{l}\text { Ratio of the volume of characters of the SGP construct over the total characters } \\
\text { of the mission statement. Serves to demonstrate the expressivity of the construct, } \\
\text { considering the mission as a whole. Should only include the companies that } \\
\text { disclosed the SGP construct. }\end{array}$ \\
\hline Smoothing & $\frac{C x}{C S x}$ & $\begin{array}{l}\text { Ratio of the volume of characters of the SGP construct over the sampling volume } \\
\text { of companies of the sector. }\end{array}$ \\
\hline Concealment & $\frac{(\text { Sur }+ \text { Gro }+ \text { Pro })}{3}$ & $\begin{array}{l}\text { Mean of the presence of the survival, growth, and profitability constructs. } \\
\text { Understood as the suppression of at least one of the three core concepts in the } \\
\text { component. }\end{array}$ \\
\hline $\begin{array}{l}\text { Discourse balance - } \\
\text { Bart's criterion (2006) }\end{array}$ & $\frac{P}{C S x}$ & $\begin{array}{l}\text { Ratio of the volume of words of the construct over the sampling volume of } \\
\text { companies of the sector. Shows the level of balance in the mission statements. }\end{array}$ \\
\hline
\end{tabular}

$A C=$ sum of the constructs included in the sector's mission statements; Gro = quantity of the growth concept in the total construct of the sector; $C x=$ total volume of characters of construct $x$ of the sector; CSx = sampling volume of companies of the sector; Pro = quantity of the profitability concept in the total construct of the sector; $P=$ volume of terms of construct $x$ of the sector; SGP = survival, growth, and profitability construct; Sur = quantity of the survival concept in the total construct of the sector.

Source: Elaborated by the authors.

As already mentioned, after analyzing the disclosure of the construct and its components, the CSD qualitative analysis technique was applied, with the aim of identifying the social representation and collective thinking of the sectors (Lefevre \& Lefevre, 2005). This methodology consists of analyzing verbal, discursive, or textual elements to extract core ideas (CI) and anchors (AC) based on the literal fragments or transcriptions known as correlated key expressions (KEX). This analysis enabled the synthesis to be composed of the discourses of the companies of each sector, the CSDs. 
In this research, the KEX refer to passages from each mission statement analyzed. The $\mathrm{CI}$ are the sets of partial KEX from the mission statements that refer to one type of anchor. The AC are the components. The CSDs, as synthesis discourses, were built using the set of KEX of each anchor type of the component. Following the recommendations of Creswell (2010) and Lefevre and Lefevre (2005), textual interpretations of the authors of this research were used to categorize and synthesize the data and to identify the social representations contained in the mission statements of the companies that composed the sample.

\section{RESULTS ANALYSIS}

\subsection{Descriptive Analysis of the SGP Construct}

The recurrent words for building the SGP construct were: "shareholders" (45), "value" (17), "profitability" (14), "generating" (12), "our" (10), "partners" (7) "profitable" (6), "growth" (5), "return" (5), "form" (5), "development" (5), and "economic" (5). It is observed that the word "shareholders" represents $12 \%$ of the 368 words of the SGP construct used by the companies participating in the sample, indicating that this is the most highlighted stakeholder in the mission statements analyzed. The results resemble those obtained by Cady et al. (2011), who identified, among the frequent terms: "shareholder return/value" (255) in $1^{\text {st }}$ place, "financial performance/ profitability" (210) in $4^{\text {th }}$ place, and "business expansion/ growth" (137) in $10^{\text {th }}$ place.

The analysis of Table 2 indicates that $56.4 \%$ of the companies omitted the SGP construct in their mission statements; that is, most were silent regarding the expectations for growth, profitability, and survival. This may be explained by the lack of concern about the effect of future events on organizational growth or the companies being more orientated toward the short term
(Najimudinova, 2018). This omission percentage is higher than that of Mussoi et al. (2011), who, for a sample of 140 publicly-traded Brazilian companies, identified that $42 \%$ did not disclose the SGP construct.

The results show that only the Mining and Textiles sectors saw the totality of their companies disclose the SGP construct in their mission statements. In contrast, the Capital Goods, Communications, and Various sectors did not present any company that disclosed the construct and, consequently, these sectors were excluded from the subsequent analyses.

Of the sectors that disclosed the SGP construct, 90\% (18) only do so partially. Considering that its components are strongly interlinked (Pearce \& David, 1987), there is a risk, for example, of focusing on organizational profitability, without considering the continuity of the business, or focusing on survival, without considering long-term profitability. The risk of a lack of balance between the components of the construct appears to be higher for the sectors related to Transport and Services, thus corroborating the findings of Rajasekar (2013); that is, the Automotive Industry, Retail, and Health Services sectors had the worst level of disclosure of the construct (Table 2).

Table 2

Disclosure of the survival, growth, and profitability (SGP) construct by sector

\begin{tabular}{|c|c|c|c|}
\hline Sector & $\begin{array}{l}\text { Quantity of companies } \\
\text { (n) }\end{array}$ & $\begin{array}{c}\text { Discloses the construct } \\
(\%)\end{array}$ & $\begin{array}{c}\text { Does not disclose the construct } \\
(\%)\end{array}$ \\
\hline Mining & 3 & 100.0 & 0.0 \\
\hline Textiles & 2 & 100.0 & 0.0 \\
\hline Pharmaceuticals & 4 & 75.0 & 25.0 \\
\hline Agricultural Production & 13 & 69.2 & 30.8 \\
\hline Steelmaking and Metallurgy & 10 & 60.0 & 40.0 \\
\hline Chemicals and Petrochemicals & 15 & 53.3 & 46.7 \\
\hline Electronics & 4 & 50.0 & 50.0 \\
\hline Telecommunications & 4 & 50.0 & 50.0 \\
\hline Energy & 35 & 48.6 & 51.4 \\
\hline Consumer Goods & 18 & 44.4 & 55.6 \\
\hline Wholesale & 21 & 42.9 & 57.1 \\
\hline Construction Industry & 7 & 42.9 & 57.1 \\
\hline Digital Industry & 7 & 42.9 & 57.1 \\
\hline Infrastructure & 7 & 42.9 & 57.1 \\
\hline Services & 7 & 42.9 & 57.1 \\
\hline Pulp and Paper & 3 & 33.3 & 66.7 \\
\hline
\end{tabular}


Table 2

Cont.

\begin{tabular}{|c|c|c|c|}
\hline Sector & $\begin{array}{l}\text { Quantity of companies } \\
(\mathbf{n})\end{array}$ & $\begin{array}{c}\text { Discloses the construct } \\
(\%)\end{array}$ & $\begin{array}{c}\text { Does not disclose the construct } \\
(\%)\end{array}$ \\
\hline Transport & 9 & 33.3 & 66.7 \\
\hline Automotive industry & 11 & 27.3 & 72.7 \\
\hline Retail & 22 & 27.3 & 72.7 \\
\hline Health Services & 11 & 18.2 & 81.8 \\
\hline Capital Goods & 3 & 0.0 & 100.0 \\
\hline Communications & 2 & 0.0 & 100.0 \\
\hline Various & 2 & 0.0 & 100.0 \\
\hline Total & 220 & 43.6 & 56.4 \\
\hline
\end{tabular}

Source: Elaborated by the authors based on empirical data.

Regarding the disclosure of the components of the SGP construct by the sectors (Table 3 ), it is observed that $40 \%$ $(8 / 20)$ of these disclose the totality of the components, $40 \%$ (8/20) disclose most of the components, and 20\% (4/20) only disclose one of the components of the construct. It is worth highlighting that the disclosure, even when partial and not including all the companies, indicates that there is a discourse of the sector about the construct. The sectors linked to attending to public needs, such as Infrastructure, Health Services, and Transport, are those that most silence the discourse about survival, growth, and profitability, with only one of the components being disclosed by the companies of those sectors.

The global analysis of the sectors indicates that the profitability component was the most disclosed (90\%), followed by the growth (85\%) and survival (45\%) components. This result diverges from the findings of Sufi and Lyons (2003), who, when investigating the relationship between the financial success of hotel businesses and the quality of their mission statements, identified that $86 \%$ of the companies express concern about survival in their statements.

Table 3

Disclosure of the components of the survival, growth, and profitability (SGP) construct by sector

\begin{tabular}{|c|c|c|c|c|}
\hline \multirow{2}{*}{ Sector } & \multicolumn{3}{|c|}{ Components of the SGP construct } & \multirow{2}{*}{$\begin{array}{l}\text { Disclosure of the construct } \\
(\%)\end{array}$} \\
\hline & Profitability & Growth & Survival & \\
\hline Wholesale & Yes & Yes & Yes & 100.0 \\
\hline Energy & Yes & Yes & Yes & 100.0 \\
\hline Construction Industry & Yes & Yes & Yes & 100.0 \\
\hline Digital Industry & Yes & Yes & Yes & 100.0 \\
\hline Agricultural Production & Yes & Yes & Yes & 100.0 \\
\hline Chemicals and Petrochemicals & Yes & Yes & Yes & 100.0 \\
\hline Steelmaking and Metallurgy & Yes & Yes & Yes & 100.0 \\
\hline Retail & Yes & Yes & Yes & 100.0 \\
\hline Automotive Industry & Yes & Yes & No & 66.7 \\
\hline Consumer Goods & Yes & Yes & No & 66.7 \\
\hline Electronics & Yes & Yes & No & 66.7 \\
\hline Pharmaceuticals & Yes & Yes & No & 66.7 \\
\hline Mining & Yes & Yes & No & 66.7 \\
\hline Pulp and Paper & No & Yes & Yes & 66.7 \\
\hline Services & Yes & Yes & No & 66.7 \\
\hline Textiles & Yes & Yes & No & 66.7 \\
\hline Infrastructure & Yes & No & No & 33.3 \\
\hline Health Services & No & Yes & No & 33.3 \\
\hline Telecommunications & Yes & No & No & 33.3 \\
\hline Transport & Yes & No & No & 33.3 \\
\hline Disclosure of the component (\%) & 90.0 & 85.0 & 45.0 & 73.3 \\
\hline
\end{tabular}

Source: Elaborated by the authors based on the empirical data. 
Table 4 presents the mean number of words used in the disclosure of the SGP construct, enabling it to be identified whether the sectors are detailing or simplifying their discourses regarding the construct. Considering Bart's (2006) parameter, which indicates that each construct of a mission statement should have between six and eight words to be considered an adequate discourse, the sectors ranked between the $5^{\text {th }}$ and $13^{\text {th }}$ position are disclosing the construct in a balanced way, while the sectors ranked from the $1^{\text {st }}$ to the $4^{\text {th }}$ position present unbalanced disclosure (Pearce, 1982), with an excessive number of words, and the sectors ranked between the $14^{\text {th }}$ and $20^{\text {th }}$ position present unsatisfactory disclosure of the SGP construct, with a reduced number of words, which ultimately makes it difficult to build a rational discourse (Verma, 2009) that can be understood by the stakeholders.

Table 4

Mean number of words of the sector for the survival, growth, and profitability (SGP) construct

\begin{tabular}{llc}
\hline & Sector & Means no. of words of the SGP construct \\
\hline $1^{\circ}$ & Pulp and Paper & 11.0 \\
\hline $2^{\circ}$ & Mining & 10.0 \\
\hline $3^{\circ}$ & Electronics & 9.0 \\
\hline $4^{\circ}$ & Health Services & 8.5 \\
\hline $5^{\circ}$ & Consumer Goods & $\mathbf{8 . 0}^{*}$ \\
\hline $6^{\circ}$ & Retail & $\mathbf{7 . 8}^{*}$ \\
\hline $7^{\circ}$ & Construction Industry & $\mathbf{7 . 3}^{*}$ \\
\hline $8^{\circ}$ & Textiles & $\mathbf{7 . 0 ^ { * }}$ \\
\hline $9^{\circ}$ & Chemicals and Petrochemicals & $\mathbf{6 . 8 ^ { * }}$ \\
\hline $10^{\circ}$ & Energy & $\mathbf{6 . 5 *}$ \\
\hline $11^{\circ}$ & Transport & $\mathbf{6 . 3 *}$ \\
\hline $12^{\circ}$ & Wholesale & $\mathbf{6 . 2 *}$ \\
\hline $13^{\circ}$ & Agricultural Production & $\mathbf{6 . 0}^{*}$ \\
\hline $14^{\circ}$ & Automotive industry & 5.3 \\
\hline $15^{\circ}$ & Telecommunications & 4.5 \\
\hline $16^{\circ}$ & Digital Industry & 4.0 \\
\hline $17^{\circ}$ & Steelmaking and metallurgy & 3.7 \\
\hline $18^{\circ}$ & Infrastructure & 3.3 \\
\hline $19^{\circ}$ & Services & 2.7 \\
\hline $20^{\circ}$ & Pharmaceuticals & 2.7 \\
\hline & & \\
\hline
\end{tabular}

* Sectors that disclose SGP in a balanced way.

Source: Elaborated by the authors based on empirical data.

Table 5 presents the analysis of the organizational mission statement using the number of characters criterion. Two analyses were carried out, one considering only the companies that disclosed the SGP construct and the other considering all the companies of the sector. When all the companies of the sample are considered, seven sectors (Electronics, Telecommunications, Consumer Goods,
Chemicals and Petrochemicals, Wholesale, Energy, and Construction Industry) presented a disclosure percentage close to the equilibrium, according to the number of constructs proposed by Pearce (1982) - eight items. In this case, the mean percentage per construct should be close to $12.50 \%(1 / 8)$. 
Table 5

Disclosure for the survival, growth, and profitability (SGP) construct by the number of characters - by companies and by sector

\begin{tabular}{|c|c|c|c|c|c|}
\hline \multirow[b]{2}{*}{ Sector } & \multicolumn{2}{|c|}{ SGP construct } & \multirow{2}{*}{$\begin{array}{l}\text { Characters of the } \\
\text { statement } \\
\text { (n) }\end{array}$} & \multirow{2}{*}{$\begin{array}{l}\text { Disclosure of the } \\
\text { construct per } \\
\text { company } \\
(\%)\end{array}$} & \multirow{2}{*}{$\begin{array}{l}\text { Disclosure of the } \\
\text { construct per sector } \\
(\%)\end{array}$} \\
\hline & Mean per sector & Mean per company & & & \\
\hline Textile & 38 & 65 & 149 & 25.5 & 25.5 \\
\hline Mining & 55 & 59 & 229 & 24.0 & 24.0 \\
\hline Pulp and Paper & 22 & 50 & 95 & 68.4 & 23.2 \\
\hline $\begin{array}{l}\text { Agricultural } \\
\text { Production }\end{array}$ & 26 & 37 & 154 & 24.0 & 16.9 \\
\hline Electronics & 28 & 50 & 216 & 25.9 & $13.0^{*}$ \\
\hline Telecommunications & 14 & 37 & 111 & 26.1 & $12.6^{*}$ \\
\hline Consumer Goods & 22 & 40 & 176 & 28.4 & $12.5^{*}$ \\
\hline $\begin{array}{l}\text { Chemicals and } \\
\text { Petrochemicals }\end{array}$ & 24 & 29 & 198 & 22.7 & $12.1^{*}$ \\
\hline Wholesale & 16 & 56 & 135 & 27.4 & $11.9^{*}$ \\
\hline Energy & 20 & 38 & 175 & 24.0 & $11.4 *$ \\
\hline Construction Industry & 17 & 37 & 149 & 26.8 & $11.4 *$ \\
\hline Retail & 14 & 55 & 141 & 35.5 & 9.9 \\
\hline Transport & 12 & 42 & 124 & 29.8 & 9.7 \\
\hline Digital Industry & 10 & 45 & 108 & 22.2 & 9.3 \\
\hline Health Services & 11 & 24 & 142 & 41.5 & 7.7 \\
\hline Infrastructure & 9 & 36 & 143 & $15.4^{* *}$ & 6.3 \\
\hline $\begin{array}{l}\text { Steelmaking and } \\
\text { Metallurgy }\end{array}$ & 14 & 22 & 231 & $10.0^{* *}$ & 6.1 \\
\hline Automotive industry & 10 & 23 & 173 & 20.8 & 5.8 \\
\hline Pharmaceuticals & 10 & 13 & 174 & 7.5 & 5.7 \\
\hline Services & 7 & 17 & 270 & 6.3 & 2.6 \\
\hline
\end{tabular}

* Balance in the disclosure of the SGP construct by sector; ** balance in the disclosure by company, excluding those that did not disclose the SGP construct.

Source: Elaborated by the authors based on empirical data.

However, when considering only the companies that disclosed the SGP construct, the Infrastructure and Steelmaking and Metallurgy sectors were the ones that presented the most balanced discourse. This criterion is more appropriate, as it excludes the silent discourse of the companies that did not disclose the construct. According to the number of characters criterion, most of the sectors present little objectivity in their discourse, with high disclosure percentages, which may indicate a concealed discourse or one lacking the rationality recommended by the TRA (Verma, 2009). At the other extreme, the Services and Pharmaceutical sectors present a discourse with little possibility of disclosing the construct to the stakeholders, due to the reduced number of characters.

\subsection{Qualitative Analysis of the CSDs for the SGP Construct}

Based on the previous analyses, the CSDs of the economic sectors were built, formed based on the set of KEX for the construct of each sector and disclosed in Table 6. One example of a sector that adequately discloses the three components of the SGP construct is the Energy sector: "increasingly creating value and return for the shareholders and partners, through dividends, interest on own capital, cash generating capacity, return on investments, obtaining profitable results in the search for excellence." The Transport sector, in turn, can be considered an example of a sector that fails in the disclosure of the construct, by only disclosing profitability: "profitable, considering the shareholders' interests." 
Table 6

Collective Subject Discourse (CSD) by sector for the survival, growth, and profitability (SGP) construct

\begin{tabular}{|c|c|}
\hline Sector & CSD-SGP \\
\hline Wholesale & $\begin{array}{l}\text { "generating economic-financial development and strength through the partnerships to serve the } \\
\text { shareholders and partners with a consolidated brand" }\end{array}$ \\
\hline Automotive Industry & "that shareholder results guarantee growth and ensure profitable growth for the shareholders" \\
\hline Consumer Goods & $\begin{array}{c}\text { "generating economic value and return for the shareholders, adding value for the partners, creating long- } \\
\text { lasting bonds" }\end{array}$ \\
\hline Electronics & "ensuring profitable growth for the shareholders" \\
\hline Energy & $\begin{array}{c}\text { "increasingly creating value and return for the shareholders and partners, through dividends, interest on } \\
\text { own capital, cash generating capacity, return on investments, obtaining profitable results in the search for } \\
\text { excellence" }\end{array}$ \\
\hline Pharmaceuticals & "generation and sharing of value with the shareholders for a profitable operation" \\
\hline Construction Industry & "to generate profit for the shareholders, giving continuity to the business and to its financial health" \\
\hline Digital Industry & $\begin{array}{c}\text { "to maximize the creation of value for the shareholders, investors, and the whole ecosystem of } \\
\text { partnerships" }\end{array}$ \\
\hline Infrastructure & $\begin{array}{c}\text { "with a focus on return, in order to satisfy the shareholders, generating value for the interested parties, } \\
\text { thus fulfilling the economic role" }\end{array}$ \\
\hline Mining & $\begin{array}{c}\text { "with gold as the main focus to create value for the social partnerships, providing an adequate return on } \\
\text { investments for the shareholders" }\end{array}$ \\
\hline Pulp and Paper & "to build a relationship of trust with the shareholders and partners" \\
\hline Agricultural Production & $\begin{array}{c}\text { "to promote long-term relationships in the market, generating profit, income, economic results, and well- } \\
\text { being for the associates" }\end{array}$ \\
\hline Chemicals and Petrochemicals & $\begin{array}{c}\text { "for us to achieve and maintain above-average profitability for our shareholders with growth, favoring the } \\
\text { commercial partnerships, strengthening the company's profit-making capacity, and what we represent as } \\
\text { a brand" }\end{array}$ \\
\hline Health Services & "to provide conditions for corporate and comparative development and improvement" \\
\hline Services & "to contribute to the success of the business, being profitable for the shareholders" \\
\hline Steelmaking and Metallurgy & $\begin{array}{c}\text { "contributing to the success of our shareholders, so as to create profitable, long-lasting, and replicable } \\
\text { relationships" }\end{array}$ \\
\hline Telecommunications & "generating value for the shareholders" \\
\hline Textiles & "generating return for the company and partners by creating value for the shareholders" \\
\hline Transport & "profitable, considering the shareholders' interests" \\
\hline Retail & $\begin{array}{c}\text { "strengthening the brand, aiming to create long-lasting relationships that generate value for all and for the } \\
\text { shareholders, guaranteeing continuity, permanent and constant growth of the company, and the expansion } \\
\text { of the business, thus achieving a sound financial footing" }\end{array}$ \\
\hline
\end{tabular}

Source: Elaborated by the authors based on empirical data.

The CSDs by sectors are analyzed in Table 7 regarding the content of the discourse of the Brazilian economic sectors; that is, referential interpretations are made by the authors of this study, following the CSD methodology, where brief inferences and reflections are made, considering the concepts of the construct investigated. It is recommended that these inferences are analyzed together with the information in tables 2 and 6 to better understand the analysis methodology and interpretation of the results.

\section{Table 7}

Analyses of the Collective Subject Discourses (CSDs)

WHOESALE - The concern of the sector lies in developing the economy and in strengthening partnerships. Economic development is linked to profit generation. The strengthening of partnerships can be understood as prioritizing the relationship with partners, aiming to serve the shareholders, enabling growth. Brand consolidation leads to market survival.

AUTOMOTIVE INDUSTRY - Shareholder results are what guarantees and ensures profitable growth. Guaranteeing and ensuring refer to the idea of obtaining profitability and maintaining it at an acceptable level, unlike the idea of Delmar et al. (2013), where profitability leads to survival, growth, and profitability; in this case, profitability in the form of shareholder results leads to growth. The inversion of this logic may perhaps signal greedy behavior, as mentioned by Demsetz (1997), by not prioritizing survival and growth in the discourse in relation to profitability. Profitability is a core concept of the component, but only in relation to growth, as survival is not mentioned. 


\section{Table 7}

Cont.

CONSUMER GOODS - The sector mentions the generation of value and profitability for the shareholders while adding to the partners. Profitability is objective and expressed. And it mentions the "creation of long-lasting bonds," which is a concern with growth. Company survival is not clearly mentioned.

ELETRONICS - The emphasis of this discourse lay in "ensuring profitable growth." The expression "profitable growth" synthesizes the elements in the component. The discourse does not detail this and does not mention survival. The application of the term "ensure" perhaps signals that the sector has already achieved desirable levels of profitability and that its efforts are focused on maintaining those levels.

ENERGY - The energy sector is more specific in portraying the component, as it mentions the creation of profitability and growth through partnerships and specifies the means for this. The discourse makes explicit the possibility of there being "unprofitable results." The sector states that profitable results are achieved during the search for excellence. Company survival in this sector may be associated with that search.

PHARAMCEUTICALS - The capacity to generate and strengthen value (profitability) is highlighted. The value generated is shared with the shareholders. There is an emphasis on sharing that leads to a "profitable operation." Sharing value is indicative of growth, which leads to profitability.

CONSTRUCTION INDUSTRY - The term "profit" is used emphatically. The terms "continuity" and "financial health" relate to the nature of growth and survival.

DIGITAL INDUSTRY - There is a search to maximize the value created, which can be understood as profit maximization of the shareholders, investors, and partners. This discourse expands the limits of profitability to the partners, thinking of the supply chain. The "ecosystem of partnerships" may indicate that the growth and/or survival of the companies of the sector depend on this.

INFRASTRUCTURE - "Shareholder satisfaction" is emphasized. "Value creation for the interested parties" refers to the generation of value for the shareholders, with a specific focus on profitability. Fulfillment of the economic role may create the understanding that serving the shareholder is fulfilling the economic role.

MINING - Gold is the companies' focus in the process of "creating value for the social partners." The term "social" highlights the recognition of the relationships for growth. The expression "adequate return" indicates the type of return sought by the companies of the sector, making it implicit that "inadequate return" is possible. The discourse may lead to the idea that the companies have provided, in the past, an unexpected return for the shareholders. Survival is not clearly mentioned.

PULP AND PAPER - Building trust, as a component, highlights the discourse of this sector. Relationships of trust with the shareholders can indicate survival and relationships of trust with the partners can indicate growth in the market. There is no specific mention of return or profitability, although building trust with the "shareholders and partners" can lead to profitability.

AGRICULTURAL PRODUCTION - The sector aims to promote a long-term relationship in the market by thinking about growth and survival. It makes it clear that it desires the generation of profit, income, and economic results, but complements this by mentioning a philosophical component of wanting to generate "well-being" for the associates or beneficiaries (shareholders) through the profit generated.

CHEMICALS AND PETROCHEMICALS - There is a clear desire to achieve and maintain profitability. The term "above average" may indicate that the evolution of profitability is closely monitored. The sector desires growth and the commercial partners are beneficiaries of that growth. The company's survival is stated through "strengthening the ability to make a profit" and the brand's representativeness in the market.

HEALTH SERVICES - Profitability and survival are not mentioned, but growth is highlighted as being based on the development and improvement of the corporate and comparative aspects.

SERVICES - The "contribution to business success" and the need to be "profitable for the shareholders" are pillars of the component for the sector. "Business success" may indicate effective growth in the market, while "profitable" may represent the desire to obtain profits in order to serve the shareholders.

STEELMAKING AND METALLURGY - "Contribution to the success of the business" is mentioned. By highlighting the long-lasting, profitable, and replicable relationship, the closeness between the concepts of growth, profitability, and survival is demonstrated.

TELECOMMUNICATIONS - The discourse of this sector is very lean and brief. Generating value for the shareholders is the aim of the sector, relating to profitability, with no expression of survival and growth aspects.

TEXTILES - The "generation of return" is related to the company and the partners, valuing the supply chain and growth and dependence on value creation. This mitigates growth. "Generation of return" and "value creation" may be similar expressions. If they are, there is an order of priorities for value generation: shareholders, companies, and partners. Survival is not clearly mentioned.

TRANSPORT - Profitability is associated with the shareholders' interests. There is no explicit mention of the concepts of survival and growth.

RETAIL - The concepts growth and survival are highlighted by the emphasis on "strength of the brand," the "long-lasting relationship," "permanent growth," and "continuity." Value creation is not limited to the shareholders, but is extended to all. The major concern is with the expansion of the business to obtain a strong financial footing. Profitability is expressed in the terms "value" and "financial."

Source: Elaborated by the authors based on empirical data. 


\subsection{Results Discussion}

According to the mission statements of the companies analyzed, the shareholders are the main stakeholders mentioned. The terms "shareholders," "value," and "profitability" are the main ones used to express the SGP construct. "Satisfying the shareholders," "creating and adding value," "generating profitability," "strengthening partnerships," and "adding and being profitable" are also aspects that describe the construct involved in maximizing shareholder return.

However, considering that the sample is composed of for-profit companies, this hypothesis would be unlikely. Another possibility would be the lack of a discursive rationality criterion, which, according to Rajasekar (2013), may explain the non-inclusion of the construct, given that the creation of the mission statement would be the result of some need expressed for the different stakeholders.

From the TRA perspective, the exclusion of the SGP construct reveals a behavior that silences the discourse and, consequently, the action of the managers regarding the maximization of profitability for the shareholder over the long run. Perhaps, for the companies, this component is insufficient to distinguish one organization from another (Bakoğlu \& Aşkun, 2007). However, it is risky to believe that survival, growth, and profitability are implied for the various stakeholders, as these concepts may be interpretted differently by the players involved.

Another question that may explain the silence regarding the SGP construct derives from the fact that, although mission statements serve to direct strategy, they are also more recognized in the literature as a marketing item than as an element of strategic management, thus corroborating the findings of Souza et al. (2014). The aim of marketing relies on the use of this by the internal stakeholders as a means to explain to the external public the goal and philosophy of the organization (Davies \& Glaister, 1997). The mission statement, for merely decorative purposes and also a possible explanation with regard to the silence concerning SGP, denotes its nonrational application, contradicting the rationality of the discourse recommended by the TRA.

The emphasis of the profitability and growth components in the mission statement of the sectors studied may be explained by the fact that they are concepts, according to the model of Schaffer (1989), for the long term. As the mission statement is a long-term strategic tool, the little emphasis on survival in the discourse may indicate that the companies do not wish to indicate their competitive position in the market (Delmar et al., 2013) or that the actions for obtaining return on sales over the short run, in most of the sectors, are not well defined to the point of the discourse containing them. The Infrastructure, Health Services, Telecommunications, and Transport sectors lack two of the three concepts, drawing attention to the fact that they are sectors that provide services needed by the public. These sectors, with the exception of the Health Services sector, emphasize mentioning shareholders, corroborating the evidence of Mussoi et al. (2011) that mission statements give more importance to shareholders than to profitability itself.

In the cases in which there is no explicit mention in the CSDs regarding survival and growth, it is possible to infer that, despite being concealed, these components are related, underlying, or intrinsic to the profitability aspect, corroborating the idea of Delmar et al. (2013) that profitability is a core concept of the construct because it communicates how well the company is doing in relation to the competitive pressure. In this logic, despite the sectors not including their competitive position in their discourse through the survival component, they did so through profitability. All the sectors, with the exception of Health Services and Pulp and Paper, which did not express profitability, concealed the SGP components.

Services and Infrastructure, which had a more imbalanced discourse with low expressivity, are the sectors that smooth it the most. It is speculated that these sectors do not wish to comment regarding the SGP construct, but rather engage in minimum discourse. From the rational view, these sectors understand that SGP does not contribute to expressing their senses of future direction, which may be an indication of disinterest or failure in strategic planning. The CSD of the Energy sector is the most specific in portraying the component and is not presented at the extremities in the qualifications criteria.

Judging by the discourses, the Health Services and Pulp and Paper sectors are focused on survival in the market and growth, being more geared toward changing strategic position and increasing actual sales than toward profitability itself.

The CSDs of the Textiles and Mining sectors are the most commendable, as they have more discursive detail, little smoothing, little omission, and more balance, being expressive to the point of addressing SGP, in terms of relative score, as the most important attribute among those in the mission statement. However, both conceal, not mentioning survival. The social representation of their CSDs involves growth as a concept underlying profitability. For the Textiles sector, value creation primarily occurs for the shareholders, without neglecting other companies and partners. The Mining sector has mission statement 
components that differ from the other sectors, such as the mention of "gold" as a means for obtaining return and the emphasis on social partners. It is noted, however, that the reduced sampling volume may have contributed to that distinctive aspect.

Retail, the Automotive Industry, and Transport omitted the components the most. The Retail and Transport sectors omit and produce unbalanced discourse, with reasonable expressivities and smoothing; however, Retail presents the construct with all the components, emphasizing growth and survival, while Transport conceals, placing the focus on profitability. Retail shows economic concern in wishing to strengthen the brand and create long-term relationships. The dependency of Retail on logistics systems for e-commerce may have created an alignment in these aspects.

The Automotive Industry omits and produces unbalanced discourse, with low expressivity. It is one of the sectors that smooth the discourse the most, concealing the construct by not mentioning survival. This may be an indication of greed, but rationally it may be concerned about really guaranteeing and ensuring profit in the dynamics of the market, although it generally achieves it. In any case, it cannot be assumed that what is stated in the missions corresponds to the real organizational behavior and beliefs. Companies may have a mission statement that is not actually implemented (Alegre et al., 2018) and/or disclosed.

\section{CONCLUDING REMARKS}

The aim of this study was to verify the level of disclosure of the SGP construct in the mission statements of Brazilian companies and in the collective discourse of different economic sectors, classified according to the Biggest \& Best Annual published by Exame Magazine.

The descriptive analysis was carried out based on the research developed by Pearce (1982) and Pearce and David (1987), and the results indicate that only $40 \%$ of the sectors disclose all the components of the SGP construct and most (55\% according to the number of words criterion and $90 \%$ according to the number of characters criterion) of the sectors adopt quite an unbalanced discourse, that is, with little objectivity or lacking the expressivity needed to understand the long-term objectives for the three components.

Applying CSD regarding the mission statements and qualifying them to understand if the economic sectors are disclosing the SGP construct with smoothing, concealment, omission, or with expressivity and balance, results were obtained that suggest that the mission statements, with regard to the SGP construct, are not well defined. Supporting this conclusion is the fact that more than half the companies do not include the construct in their statements and those that do speak with discursive vagueness, lacking clarity in the disclosure of the SGP components. Silence or discursive vagueness indicate a lack of rationality, as recommended by the TRA (Verma, 2009), in the elaboration of companies' mission statements and, consequently, in the building of a CSD for the sectors studied. Based on this result, a need was identified to review the formulation of the mission statements of the companies in the sample, with the aim of improving communication of the SGP construct to the different stakeholders, and, considering the importance of the mission statements to the strategic planning process (Frezatti, 2017), increasing the probability of success in its elaboration, communication, and implementation.

The companies that disclose the SGP construct, $43.64 \%$ of the sample, are representative of $87 \%$ of the sectors analyzed. The Capital Goods, Communications, and Various sectors do not disclose the SGP construct, which may indicate a lack of rationality among them when communicating their mission statements (Verma, 2009). Among the possible reasons for non-inclusion (or omission) of the SGP construct are: lack of knowledge, judgment that the construct is not relevant, lack of rationality in the elaboration of the mission statement due to shortcomings in people's motivation and in the formation and disclosure of an organizational identity, and the use of the mission statement as a marketing instrument or decoration.

In general, the economic sectors analyzed avoid speaking about raising sales and surviving in the market or address this as intrinsic to profitability, meaning this stands out from the other components, in most cases, creating concealment and/or an omission in the communication of the strategic planning.

Therefore, the presence of the SGP construct does not imply that its three components are present in the discourses, as concealment occurs through the suppression of at least one of the components. Infrastructure, Telecommunications, Transport, and Health Services are the most concealed. The first three do not disclose their plans for the growth and survival components, while the Health Services sector silences the aspects related to profitability and growth. Attention is drawn to the fact that these sectors are linked to public utility and health services. However, the results do not enable inferences regarding the motives for the low disclosure in these sectors. 
Considering the rational writing recommended by the TRA (Fishbein \& Ajzen, 2015) and the number of words recommended by Bart (2006), it was found that the Steelmaking and Metallurgy, Infrastructure, and Services sectors are the ones that have the shortest discourses, with little expressivity and, therefore, with problems in communicating to the stakeholders. Conversely, the discourses of the Pulp and Paper and Mining sectors have a greater number of words and little balance, with the aggravating factor of only disclosing two of the three components of the construct.

The sectors that presented the most adequate discourse for the SGP construct, disclosing the three components (Pearce, 1982), and in the interval of six to eight words (Bart, 2006), were Retail, Chemicals and Petrochemicals, Construction Industry, Energy, Wholesale, and Agricultural Production. However, when considering the eight components proposed by Pearce (1982) and Pearce and David (1987), there is an observed lack of balance in the discourse of the mission statements of these sectors.

The limitation of the findings of this research derive from the fact that the CSDs are a social representation of the sectors analyzed and, for that reason, may not represent the individual discourse, as the collective expression of the strategic actions and of the expected behavior of the different sectors prevails in it.

Despite this limitation, the results reinforce the need to establish a mission statement that discloses all the constructs needed for the organization's long- term planning, in order to enable the shareholders to understand the business and the direction that should be given to the strategic objectives to be determined in the strategic planning.

By dividing the mission statements into components and attributing different weights to these, considering only the written discourse, the same weight is ultimately given to all the components of the construct analyzed. The reference to the three components of the SGP construct does not mean that all are equally important or that the relevance of the components is the same for the different companies. These aspects should be considered as a limitation of this study.

The same situation could apply to the mention of terms in the discourse. However, although weight is not attributed to the concepts, these are aligned with the components of the mission statements through the qualification methodology created, which tries to avoid the criticism of Alegre et al. (2018) regarding similarity in the attribution of importance of the components.

Finally, it is suggested that information collected through interviews in subsequent research could complement the discourses of the companies in future replications, validating their real collective discourse in the establishment of the mission statements and, consequently, in the elaboration of their forerunner, strategic planning. In due course, the motivations of companies that lead to them omitting the SGP construct could be investigated.

\section{REFERENCES}

Albert, S., \& Whetten, D. A. (1985). Organizational identity. Research in Organizational Behavior, 7, 263-295.

Alegre, I., Berbegal-Mirabent, J., Guerrero, A., \& Mas-Machuca, M. (2018). The real mission of the mission statement: A systematic review of the literature. Journal of Management \& Organization, 24(4), 456-473.

Bakoğlu, R., \& Aşkun, B. (2007). Mission statements of socially responsible firms: A content analysis. Journal of Global Strategic Management, 1(1), 66-74.

Bart, C. K. (1997). Sex, lies, and mission statements. Business Horizons, 40(6), 9-18.

Bart, C. K. (2006). Mission profitable. The Canadian Manager, 31(3), 20.

Bartkus, B., Glassman, M., \& Bruce McAfee, R. (2000). Mission statements: Are they smoke and mirrors? Business Horizons, 43(6), 23-28.

Berbegal-Mirabent, J., Mas-Machuca, M., \& Guix, P. (2019). Impact of mission statement components on social enterprises' performance. Review of Managerial Science. https://doi.org/10.1007/s11846-019-00355-2

Cady, S. H., Wheeler, J. V, DeWolf, J., \& Brodke, M. (2011). Mission, vision, and values: What do they say? Organization Development Journal, 29(1), 63-78.

Campbell, A. (1991). A mission to succeed. Director, 44(7), 66.

Campbell, A., \& Yeung, S. (1991a). Brief case: Mission, vision and strategic intent. Long Range Planning, 24(4), 145-147.

Campbell, A., \& Yeung, S. (1991b). Creating a sense of mission. Long Range Planning, 24(4), 10-20.

Campbell, A. (1997). Stakeholders: the case in favour. Long Range Planning, 30(3), 446-449.

Campbell, D. (2001). Voluntary disclosure of mission statements in corporate annual reports: Signaling what and to whom? Business \& Society Review, 106(1), 65.

Certo, S. C., \& Certo, S. T. (2012). Modern management. Pearson Prentice Hall. 
Cochran, D. S., David, F. R., \& Gibson, C. K. (2008). A framework for developing an effective mission statement. Journal of Business Strategies, 25(2), 27.

Collis, D. J., \& Rukstad, M. G. (2008). Can you say what your strategy is? Harvard Business Review, 86(4), 82-90.

Creswell, J. W. (2010). Projeto de pesquisa: Métodos qualitativo, quantitativo e misto. Tradução M. Lopes ( $3^{\text {rd }}$ ed.). Artmed.

David, F. R. (1989). How companies define their mission. Long Range Planning, 22(1), 90-97.

David, F. R., \& David, F. R. (2003). It's time to redraft your mission statement. Journal of Business Strategy, 24(1), 11-14.

Davies, S. W., \& Glaister, K. W. (1997). Business school mission statements - The bland leading the bland? Long Range Planning, 30(4), 481-604.

Delmar, F., McKelvie, A., \& Wennberg, K. (2013). Untangling the relationships among growth, profitability and survival in new firms. Technovation, 33(8-9), 276-291.

Demsetz, H. (1997). Profit maximization and rational behavior. The Economics of the Firm: Seven Critical Commentarities. Cambridge University.

Drucker, P. F. (1994). The theory of business. Harvard Business Review, 72(5), 95-104.

Fishbein, M. (1967). Readings in attitude theory and measurement. Wiley.

Fishbein, M., \& Ajzen, I. (1974). Attitudes towards objects as predictors of single and multiple behavioral criteria. Psychological Review, 81(1), 59.

Fishbein, M., \& Ajzen, I. (1975). Belief, attitude, intention, and behavior: An introduction to theory and research. AddisonWesley.

Fishbein, M., \& Ajzen, I. (2015). Predicting and changing behavior: The reasoned action approach. Psychology Press.

Frezatti, F. (2017). Orçamento empresarial: planejamento e controle gerencial. Atlas.

Gooch, J., \& Perlmutter, A. (1982). Military deception and strategic surprise. Psychology Press.

Graham, J. W., \& Havlick, W. C. (1994). Mission statements: A guide to the corporate and nonprofit sectors. Garland.

Gunning, R., \& Kallan, R. A. (1994). How to take the fog out of business writing. Dartnell Corporation.

Ireland, R. D., \& Hitt, M. A. (1992). Mission statements: Importance, challenge, and recommendations for development. Business Horizons, 35(3), 34-42.

Johnson, G., Scholes, K., \& Whittington, R. (2009). Explorando a estratégia corporativa: Texto e casos. Bookman.

King, D. L., \& Case, C. J., Premo, K. M. (2013). 2012 mission statements: A ten country global analysis. Academy of Strategic Management Journal, 13(10), 627-643.

Lefevre, F., \& Lefevre, A. M. C. (2005). Discurso do Sujeito Coletivo: Um novo enfoque em pesquisa qualitativa (desdobramentos) ( $2^{\text {nd }}$ ed.). Editora da Universidade de Caxias do Sul.
Lefevre, F., \& Lefevre, A. M. C. (2014). Discurso do Sujeito Coletivo: Representações sociais e intervenções comunicativas. Texto Contexto Enferm, 23(2), 502-507.

Liang, M. (2014). The microeconomic growth. The microeconomic growth. Springer-Verlag Berlin Heidelberg.

Lipton, M. (1996). Demystifying the development of an organizational vision. Sloan Management Review, 37(4), 8393.

McKee, A., Kemp, T., \& Spence, G. (2012). Management: A focus on leaders. Pearson Australia.

Moss, T. W., Short, J. C., Payne, G. T., \& Lumpkin, G. T. (2011). Dual identities in social ventures: An exploratory study. Entrepreneurship Theory and Practice, 35(4), 805-830.

Mussoi, A., Lunkes, R. J., \& Silva, R. V. da. (2011). Missão institucional: Uma análise da efetividade e dos principais elementos presentes nas missões de empresas brasileiras de capital aberto. Revista de Gestão, 18(3), 361-384.

Najimudinova, S. (2018). Content analyses on mission statements of the mobile network operators in Kyrgyzstan. Journal of Graduate School of Social Sciences, 20(1), 133-148.

O'Gorman, C., \& Doran, R. (1999). Mission statements in small and medium-sized businesses. Journal of Small Business Management, 37(4), 59-66.

Pearce, J. A. I. (1982). The company mission as a strategic tool. Sloan Management Review (Pre-1986), 23(3), 15.

Pearce, J. A. I., \& David, F. (1987). Corporate mission statements: The bottom line. Academy of Management Executive, 1(2), 109-116.

Phillips, B. D., \& Kirchhoff, B. A. (1989). Formation, growth and survival; small firm dynamics in the US economy. Small Business Economics, 1(1), 65-74.

Rajasekar, J. (2013). A comparative analysis of mission statement content and readability. Journal of Management Policy and Practice, 14(6), 131-147.

Schaffer, M. E. (1989). Are profit-maximisers the best survivors? A Darwinian model of economic natural selection. Journal of Economic Behavior \& Organization, 12(1), 29-45.

Souza, P. de, Coral, S. M., \& Lunkes, R. J. (2014). Missão organizacional: Análise dos principais elementos propostos por Pearce II (1982) presentes nas missões dos hotéis do Sul do Brasil. Podium Sport, Leisure and Tourism Review, 3(1), 94-105.

Sufi, T., \& Lyons, H. (2003). Mission statements exposed. International Journal of Contemporary Hospitality Management, 15(5), 255-262.

Tonge, A., Greer, L., \& Lawton, A. (2003). The Enron story: You can fool some of the people some of the time. Business Ethics: A European Review, 12(1), 4-22.

Verma, H. V. (2009). Mission Statements: a study of intent and influence. Journal of Services Research. https://www.questia. com/magazine/1P3-1868361831/mission-statements-a-studyof-intent-and-influence

Williams, L. S. (2008). The mission statement. Journal of business communication, 45(2), 94-119. 